\title{
氧化铈稳定的 $\mathrm{CuO}$ 簇在 $\mathrm{CO}, \mathrm{C}_{3} \mathrm{H}_{6}$ 和 $\mathrm{NO}$ 消除中的催化性能
}

\author{
石 川 ${ }^{1,2, *}$, 徐 力 $^{1,2}$, 朱爱民 ${ }^{1,2}$, 张玉卓 ${ }^{1,2}$, 区泽棠 ${ }^{3}$ \\ ${ }^{1}$ 大连理工大学工业生态与环境工程重点实验室, 辽宁大连 116024 \\ ${ }^{2}$ 大连理工大学等离子体物理化学实验室, 辽宁大连 116024 \\ 3香港浸会大学化学系, 香港九龙塘 999077
}

摘要: 研究了 $\mathrm{CuO}$ 与 $\gamma-\mathrm{Al}_{2} \mathrm{O}_{3}$ 和 $\mathrm{CeO}_{2}$ 的相互作用, 并由此制备出能有效脱除 $\mathrm{CO}, \mathrm{C}_{3} \mathrm{H}_{6}$ 和 $\mathrm{NO}$ 的催化剂, 考察了不同载体表面 $\mathrm{CuO}$ 簇的分散稳定性和耐老化性能. 结果发现, 随 $\mathrm{CuO}$ 负载量的增加, $\mathrm{CuO}$ 簇因与 $\mathrm{CeO}_{2}$ 载体的强相互作用而稳定存在; 而在 $\gamma-\mathrm{Al}_{2} \mathrm{O}_{3}$ 表面, $\mathrm{CuO}$ 簇易聚集成较大的颗粒. 另一方面, 由于 $\mathrm{CeO}_{2}$ 本身较差的热稳定性, 表面分散的 $\mathrm{CuO}$ 在 $950{ }^{\circ} \mathrm{C}$ 高温处理后 烧结. 因此, 基于 $\gamma-\mathrm{Al}_{2} \mathrm{O}_{3}$ 载体优越的耐老化性能, 在 $\gamma-\mathrm{Al}_{2} \mathrm{O}_{3}$ 载体分散 $\mathrm{CeO}_{2}$, 然后再担载 $\mathrm{CuO}$, 从而得到了稳定的 $\mathrm{CuO}$ 簇, 所 得催化剂比 $\mathrm{CuO} / \gamma-\mathrm{A}_{2} \mathrm{O}_{3}$ 和 $\mathrm{CuO} / \mathrm{CeO}_{2}$ 具有更好的催化性能和抗热老化性能.

关键词：氧化铜簇；稳定性；表面相互作用；一氧化碳；丙烯；一氧化氮；催化消除

中图分类号: 0643 文献标识码: A

收稿日期: 2012-04-06. 接受日期: 2012-05-09.

*通讯联系人. 电话/传真: (0411)84986083; 电子信箱: chuanshi@dlut.edu.cn

基金来源：国家自然科学基金 (20573014, 21073024); 辽宁省自然科学基金 (201102034); 中央高校基本科研业务费专项资金 (DUT12LK23).

本文的英文电子版(国际版)由Elsevier出版社在ScienceDirect上出版(http://www.sciencedirect.com/science/journal/18722067).

\section{Copper Oxide Clusters Stabilized by Ceria for $\mathrm{CO}, \mathrm{C}_{3} \mathrm{H}_{6}$, and $\mathrm{NO}$ Abatement}

\author{
SHI Chuan ${ }^{1,2, *}, \mathrm{XU} \mathrm{Li}^{1,2}$, ZHU Aimin ${ }^{1,2}$, ZHANG Yuzhuo ${ }^{1,2}$, AU Chak Tong ${ }^{3}$ \\ ${ }^{1}$ Key Laboratory of Industrial Energy and Environmental Engineering (MOE), Dalian University of Technology, Dalian 116024, \\ Liaoning, China \\ ${ }^{2}$ Laboratory of Plasma Physical Chemistry, Dalian University of Technology, Dalian 116024, Liaoning, China \\ ${ }^{3}$ Department of Chemistry, Center for Surface Analysis and Research, Hong Kong Baptist University, Kowloon Tong 999077, \\ Hong Kong, China
}

\begin{abstract}
A strong interaction between a metal oxide and support has long been indicative of its promotion of catalytic activities. In connection with this, we investigated the interaction of $\mathrm{CuO}$ with $\gamma-\mathrm{Al}_{2} \mathrm{O}_{3}$ and $\mathrm{CeO}_{2}$ for producing highly efficient catalysts for $\mathrm{CO}, \mathrm{C}_{3} \mathrm{H}_{6}$, and $\mathrm{NO}$ abatement. In particular, the dispersion and thermal aging resistance of $\mathrm{CuO}$ clusters on different supports were studied. $\mathrm{CuO}$ clusters can be stabilized by interaction with $\mathrm{CeO}_{2}$, while on $\gamma-\mathrm{Al}_{2} \mathrm{O}_{3}$ they aggregated into larger particles at high $\mathrm{CuO}$ loadings. On the other hand, due to the poor thermal stability of $\mathrm{CeO}_{2}, \mathrm{CuO}$ clusters dispersed on it were sintered during an aging treatment at $950{ }^{\circ} \mathrm{C}$. Accordingly, by pre-dispersing $\mathrm{CeO}_{2}$ on $\gamma-\mathrm{Al}_{2} \mathrm{O}_{3}$ followed by $\mathrm{CuO}$ dispersion, stabilized $\mathrm{CuO}$ clusters were obtained that were based on the superior aging resistance of the $\gamma-\mathrm{Al}_{2} \mathrm{O}_{3}$ support. Therefore, better catalytic performance and thermal aging properties were obtained with a $\mathrm{CuO} / \mathrm{CeO}_{2} / \gamma-\mathrm{Al}_{2} \mathrm{O}_{3}$ catalyst as compared with $\mathrm{CuO} / \gamma-\mathrm{Al}_{2} \mathrm{O}_{3}$ and $\mathrm{CuO} / \mathrm{CeO}_{2}$ samples.
\end{abstract}

Key words: copper oxide clusters; stability; surface interaction; carbon monoxide, propene; nitric oxide; catalytic abatement

Received 6 April 2012. Accepted 9 May 2012.

*Corresponding author.Tel/Fax: +86-411-84986083; E-mail: chuanshi@dlut.edu.cn

This work was supported by the National Natural Science Foundation of China (20573014 and 21073024), Natural Science Foundation of Liaoning Province (201102034), and the Fundamental Research Funds for the Central Universities (DUT12LK23).

English edition available online at Elsevier ScienceDirect (http://www.sciencedirect.com/science/journal/18722067). 
A surface interaction between the active component and the support influences the catalytic behavior of a supported catalyst. The dispersion of an active component is different when it is supported on different materials [1-3]. In general, a strong metal oxide/support interaction would result in a high dispersion of metal oxide, and vice versa. In addition, factors such as charge transfer, coordination environment, and redox properties should also be considered. Based on XPS analysis, An et al. [4] found that Pt on fluorinated carbon (FC) was more electron rich than Pt supported on fluorine-free supports, which was due to electron transfer from FC to Pt. Better activity and selectivity were found for the reaction of $\mathrm{NO}$ with $\mathrm{NH}_{3}$ over the $\mathrm{Pt} / \mathrm{FC}$ catalysts, which was attributed to the enhanced availability of electrons. The electron-rich Pt sites can donate electrons to NO antibonding orbitals and thereby promote dissociative chemisorption and reaction of NO. Dong and coworkers [5,6] observed that the dispersion capacity of $\mathrm{CuO}$ on $\gamma-\mathrm{Al}_{2} \mathrm{O}_{3}$ was roughly half of that on $\mathrm{MO} / \gamma-\mathrm{Al}_{2} \mathrm{O}_{3}(\mathrm{MO}=\mathrm{NiO}, \mathrm{ZnO}, \mathrm{CdO}$, and $\mathrm{MgO}$, etc.). They suggested that there was a preference incorporation of copper into the surface octahedral vacancies of $\gamma-\mathrm{Al}_{2} \mathrm{O}_{3}$ during catalyst calcination at $450{ }^{\circ} \mathrm{C}$. In an extreme case, Park et al. [7] observed the formation of the $\mathrm{CuAl}_{2} \mathrm{O}_{4}$ species when a $\mathrm{CuO} / \gamma-\mathrm{Al}_{2} \mathrm{O}_{3}$ catalyst was calcined in air at $1000{ }^{\circ} \mathrm{C}$ for $24 \mathrm{~h}$. They attributed the result to $\mathrm{Cu}^{2+}$ incorporation into the tetrahedral vacancies of the $\gamma-\mathrm{Al}_{2} \mathrm{O}_{3}$ surface. Jacobs et al. [8] reported that the reducibility of $\mathrm{CoO}$ species decreased in the order of $\mathrm{Co} / \mathrm{Al}_{2} \mathrm{O}_{3}>\mathrm{Co} / \mathrm{TiO}_{2}$ $>\mathrm{Co} / \mathrm{SiO}_{2}$, which was in line with the strength of interaction between $\mathrm{CoO}$ and the supports. In a comparison study of $\mathrm{Cu} / \mathrm{Al}_{2} \mathrm{O}_{3}$ and $\mathrm{Cu} / \mathrm{CeO}_{2} / \mathrm{Al}_{2} \mathrm{O}_{3}$ catalysts, Martinez-Arias et al. [9] observed the easier reduction of copper species with the latter and attributed the result to copper interaction with ceria entities that were well dispersed on $\mathrm{Al}_{2} \mathrm{O}_{3}$ in a two dimensional manner. They believed that the copper species with better redox properties were responsible for the catalytic oxidation of CO. In summary, a relative study based on surface interaction is helpful for understanding the catalytic activity of differently supported catalysts.

In recent years, copper-based catalysts have been extensively investigated for their superior de- $\mathrm{NO}_{x}$ properties [10-12]. In the present study, we focused on the dispersion stability and thermal stability of $\mathrm{CuO}$ clusters on $\mathrm{CuO} / \gamma-\mathrm{Al}_{2} \mathrm{O}_{3}, \mathrm{CuO} / \mathrm{CeO}_{2}$, and $\mathrm{CuO} / \mathrm{CeO}_{2} / \gamma-\mathrm{Al}_{2} \mathrm{O}_{3}$ catalysts. $\mathrm{CO}, \mathrm{NO}$, and $\mathrm{C}_{3} \mathrm{H}_{6}$ abatement was employed as the probe reaction. This is the key reaction system in the control of automotive exhaust emission. By correlating the stability of the copper species with catalytic behavior, the significance of $\mathrm{CuO}$ clusters was identified. It was found that $\mathrm{CuO}$ clusters can be stabilized by interaction with $\mathrm{CeO}_{2}$, and the thermal stability of $\mathrm{CeO}_{2}$ was enhanced by its interaction with $\gamma-\mathrm{Al}_{2} \mathrm{O}_{3}$. Therefore, pre-dispersing $\mathrm{CeO}_{2}$ on $\gamma-\mathrm{Al}_{2} \mathrm{O}_{3}$ followed by $\mathrm{CuO}$ deposition allowed $\mathrm{CuO}$ clusters to exist at high temperatures, and a good catalytic performance was achieved.

\section{Experimental}

\subsection{Catalyst preparation}

$\mathrm{CeO}_{2}$ was purchased from Rare-Chem Hi-Tech Co. Ltd., and $\gamma-\mathrm{Al}_{2} \mathrm{O}_{3}$ from Nanjing Catalyst Factory, China. The $\gamma-\mathrm{Al}_{2} \mathrm{O}_{3}$ material was calcined at $600{ }^{\circ} \mathrm{C}$ for $4 \mathrm{~h}$ before use. The $\mathrm{CeO}_{2} / \gamma-\mathrm{Al}_{2} \mathrm{O}_{3}$ binary support was prepared by incipient wetness impregnation of $\gamma-\mathrm{Al}_{2} \mathrm{O}_{3}$ with an aqueous solution of $\mathrm{Ce}\left(\mathrm{NO}_{3}\right)_{3} \cdot 6 \mathrm{H}_{2} \mathrm{O}$. The material obtained was dried at 110 ${ }^{\circ} \mathrm{C}$ for $8 \mathrm{~h}$ and subsequently heated to $800{ }^{\circ} \mathrm{C}$, with holding for $1 \mathrm{~h}$ after every rise of $100{ }^{\circ} \mathrm{C}$.

Supported $\mathrm{CuO}$ catalysts were prepared by incipient wetness impregnation of the supports with an aqueous $\mathrm{Cu}\left(\mathrm{NO}_{3}\right)_{2}$ solution that would result in a designated $\mathrm{CuO}$ loading. After drying at $110{ }^{\circ} \mathrm{C}$, the catalysts were calcined at $500{ }^{\circ} \mathrm{C}$ for $3 \mathrm{~h}$ in dry air. The $\mathrm{CuO} / \gamma-\mathrm{Al}_{2} \mathrm{O}_{3}, \mathrm{CuO} / \mathrm{CeO}_{2}$, and $\mathrm{CuO} / 10 \% \mathrm{CeO}_{2} / \gamma-\mathrm{Al}_{2} \mathrm{O}_{3}$ catalysts were denoted as $\mathrm{CuA}$, $\mathrm{CuC}$, and $\mathrm{CuCA}$, respectively. With $x$ (wt\%) $\mathrm{CuO}$ loading based on the total mass of the sample, the catalysts were denoted as $x \mathrm{CuA}, x \mathrm{CuC}$, and $x \mathrm{CuCA}$. A portion of the $7 \% \mathrm{CuA}, 7 \% \mathrm{CuC}$, and $7 \% \mathrm{CuCA}$ catalysts was subject to aging at $950{ }^{\circ} \mathrm{C}$ in air for $4 \mathrm{~h}$. The resulting materials were denoted as $\mathrm{CuA}-\mathrm{a}, \mathrm{CuC}-\mathrm{a}$, and $\mathrm{CuCA}-\mathrm{a}$, respectively.

\subsection{Catalyst tests}

Activity test of the catalysts was carried out using a fixed bed quartz reactor equipped with a coaxial thermocouple. The catalyst (ca. $0.2 \mathrm{~g}$ ) was pretreated in a $\mathrm{N}_{2}$ stream (flow rate $=60 \mathrm{ml} / \mathrm{min}$ ) at $500{ }^{\circ} \mathrm{C}$ for $1 \mathrm{~h}$ and then put in contact with a gas feed $\left(0.1 \% \mathrm{NO}+0.1 \% \mathrm{C}_{3} \mathrm{H}_{6}+1 \% \mathrm{CO}+0.9 \%\right.$ $\mathrm{O}_{2}, \mathrm{~N}_{2}$ balance) at a gas hourly space velocity (GHSV) of $50000 \mathrm{~h}^{-1}$. The effluent was analyzed online by a Foshan FGA-4100 analyzer.

\subsection{Catalyst characterization}

X-ray diffraction (XRD) analysis was carried out on a X-ray diffractometer (Rigaku D-Max Rotaflex) using $\mathrm{Cu} K_{\alpha}$ radiation $(\lambda=0.15404 \mathrm{~nm})$. UV-Vis diffuse reflectance spectra (UV-Vis DRS) were recorded in the range of 200-800 nm on a JASCO V-550 spectrometer. Temperature programmed reduction (TPR) experiments were performed with a TCD system. The sample $(50 \mathrm{mg})$ was first pretreated in an Ar stream (flow rate $=50 \mathrm{ml} / \mathrm{min}$ ) at $500{ }^{\circ} \mathrm{C}$ for $1 \mathrm{~h}$ 
and cooled to room temperature (RT). The sample was then heated $\left(10{ }^{\circ} \mathrm{C} / \mathrm{min}\right)$ from 30 to $600{ }^{\circ} \mathrm{C}$ in a flow (rate $=50$ $\mathrm{ml} / \mathrm{min}$ ) of $5 \mathrm{vol} \% \mathrm{H}_{2}$ in Ar for TPR characterization.

\section{Results and discussion}

\subsection{Dispersion stability of copper oxide clusters}

Figure 1 shows the $\mathrm{XRD}$ patterns of the catalysts with different $\mathrm{CuO}$ loadings on $\gamma-\mathrm{Al}_{2} \mathrm{O}_{3}, \mathrm{CeO}_{2}$, and $\mathrm{CeO}_{2} /$ $\gamma-\mathrm{Al}_{2} \mathrm{O}_{3}$. As can be seen in Fig. 1(a), the catalyst with the smallest $\mathrm{CuO}$ loading (3 wt \%) showed no $\mathrm{CuO}$ peaks, implying that the copper species were highly dispersed. At or above $7 \mathrm{wt} \%$ loading, peaks attributable to $\mathrm{CuO}$ crystallites

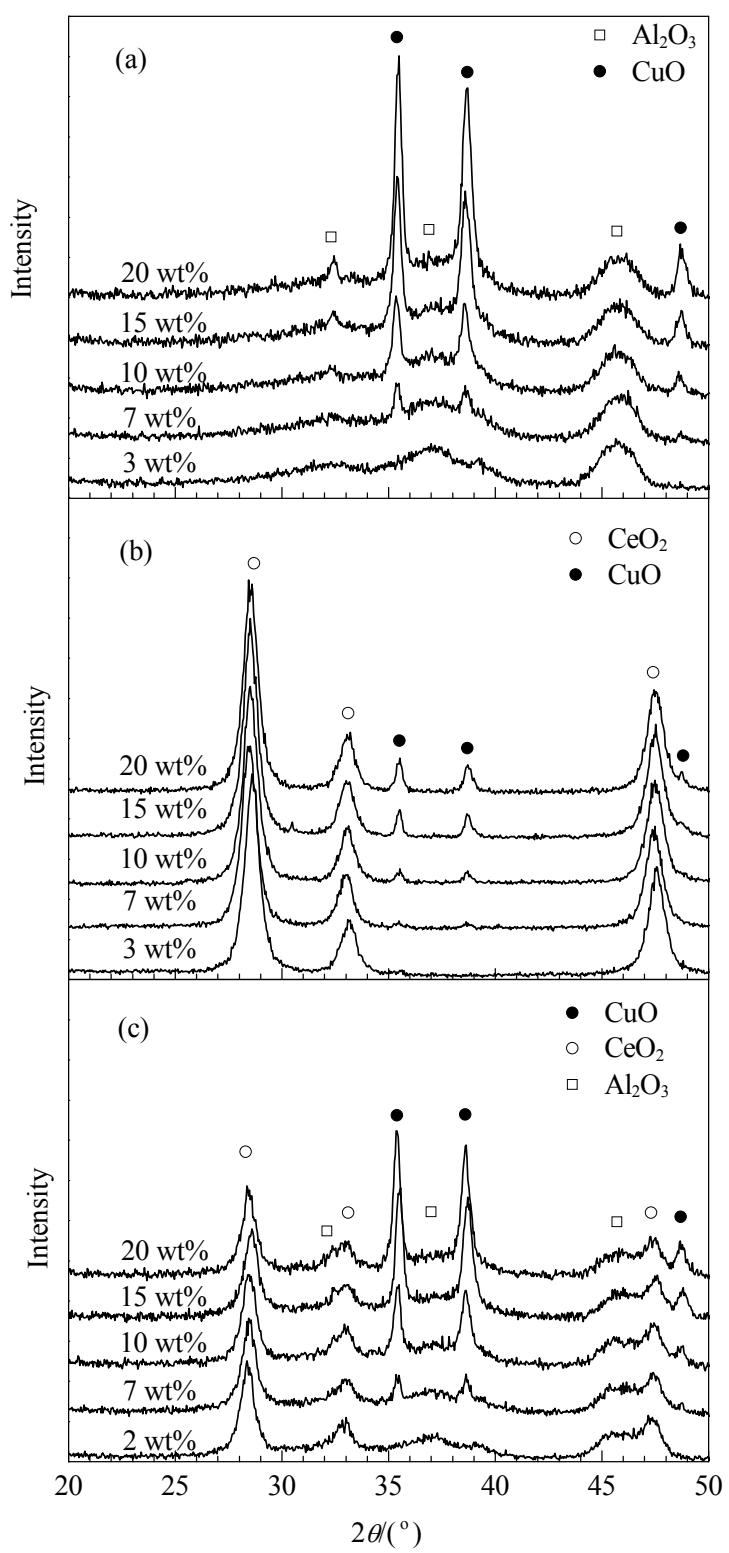

Fig. 1. XRD patterns of $\mathrm{CuA}(\mathrm{a}), \mathrm{CuC}(\mathrm{b})$, and $\mathrm{CuCA}$ (c) catalysts with different $\mathrm{CuO}$ loadings. were clearly seen at $2 \theta=35.44^{\circ}$ and $38.78^{\circ}$. The results revealed that the higher copper oxide loading (i.e. $7 \mathrm{wt} \%$ ) resulted in the formation of bulk $\mathrm{CuO}$ on the $\mathrm{CuA}$ catalysts. The crystallize sizes were calculated by the Scherrer equation and are listed in Table 1. For the $\mathrm{CuA}$ catalysts, the $\mathrm{CuO}$ particle grew from 22 to $24 \mathrm{~nm}$, indicating the continual aggregation of metal oxide with increasing loading amount.

Table 1 Crystallite sizes of ceria (cubic) and copper oxide

\begin{tabular}{lcccc}
\hline \multirow{2}{*}{ Sample } & $\begin{array}{c}\text { Crystallite size of } \\
\mathrm{CeO}_{2}{ }^{\mathrm{a}}(\mathrm{nm})\end{array}$ & \multicolumn{3}{c}{ Crystallite size of $\mathrm{CuO}^{\mathrm{b}}(\mathrm{nm})$} \\
\cline { 3 - 5 } & - & $22(-)$ & 23 & 24 \\
$\mathrm{CuA}$ & - & $18(32)$ & 19 & 20 \\
$\mathrm{CuC}$ & $12(63)$ & $25(-)$ & 27 & 27 \\
$\mathrm{CuCA}$ & $13(17)$ & $\mathrm{wt} \%$ & $20 \mathrm{wt} \%$ \\
\hline
\end{tabular}

${ }^{\mathrm{a}}$ Calculated from the $\mathrm{CeO}_{2}$ (111) crystallographic plane. ${ }^{\mathrm{b}} \mathrm{Calculated}$ from the $\mathrm{CuO}$ (111) crystallographic plane. Values in parentheses are the corresponding crystallite sizes of the aged samples.

The UV-Vis DR spectra (Fig. 2(a)) of CuA showed that the catalyst with $3 \mathrm{wt} \% \mathrm{CuO}$ loading had two main absorption bands: one at $235 \mathrm{~nm}$ and the other at $600-800 \mathrm{~nm}$. According to Praliaud et al. [13], Chary et al. [14], and Chen et al. [15], the band at 210-270 nm can be attributed to the $\mathrm{O}^{2-} \rightarrow \mathrm{Cu}^{2+}$ ligand-to-metal charge transfer that is characteristic of $\mathrm{Cu}^{2+}$ occupancy of isolated sites on $\gamma-\mathrm{Al}_{2} \mathrm{O}_{3}$. The broad band at $600-800 \mathrm{~nm}$ can be ascribed to the ${ }^{2} E_{\mathrm{g}} \rightarrow{ }^{2} T_{2 \mathrm{~g}}$ spin-allowed transition of $\mathrm{Cu}^{2+}$ situated in a distorted octahedral symmetry. The results indicated that at $3 \mathrm{wt} \%$ loading, the $\mathrm{Cu}^{2+}$ ions were highly dispersed on the surface of $\gamma-\mathrm{Al}_{2} \mathrm{O}_{3}$. At higher loadings ( $\geq 7 \mathrm{wt} \%$ ), the spectra showed the gradual development of an absorption edge at $740-800 \mathrm{~nm}$ ascribable to bulk $\mathrm{CuO}$, in agreement with the XRD investigation (Fig. 1(a)). It should be noted that a broad band at around $450 \mathrm{~nm}$ was also observed, which was probably related to the formation of $(\mathrm{Cu}-\mathrm{O}-\mathrm{Cu})^{2+}$ clusters highly dispersed on $\gamma-\mathrm{Al}_{2} \mathrm{O}_{3}$ [16]. According to Chen et al. [15], bulk-like $\mathrm{CuAl}_{2} \mathrm{O}_{4}$ also shows strong absorption in this region (400-500 nm). Nonetheless, in the present case the existence of $\mathrm{CuAl}_{2} \mathrm{O}_{4}$ was considered highly unlikely because the catalysts were calcined at a relatively lower temperature of $500{ }^{\circ} \mathrm{C}$.

The TPR characterization showed that the catalyst with the lowest metal oxide loading had a single reduction peak centered at $222{ }^{\circ} \mathrm{C}$ (Fig. 3(a)). At $\mathrm{CuO}$ loadings of $7 \mathrm{wt} \%$ and $10 \mathrm{wt} \%$, the $\mathrm{CuA}$ samples showed two peaks: one in the region of $190-200{ }^{\circ} \mathrm{C}$ and the other at $230{ }^{\circ} \mathrm{C}$. Over the 15 $\mathrm{wt} \%$ and $20 \mathrm{wt} \% \mathrm{CuA}$ catalysts, two overlapping peaks were also observed in the higher temperature region, at 235 and $250{ }^{\circ} \mathrm{C}$ for the former and at 242 and $255{ }^{\circ} \mathrm{C}$ for the latter. Because the $\gamma-\mathrm{Al}_{2} \mathrm{O}_{3}$ support showed no pronounced peaks during the TPR experiment (data not shown), the $\mathrm{H}_{2}$ 


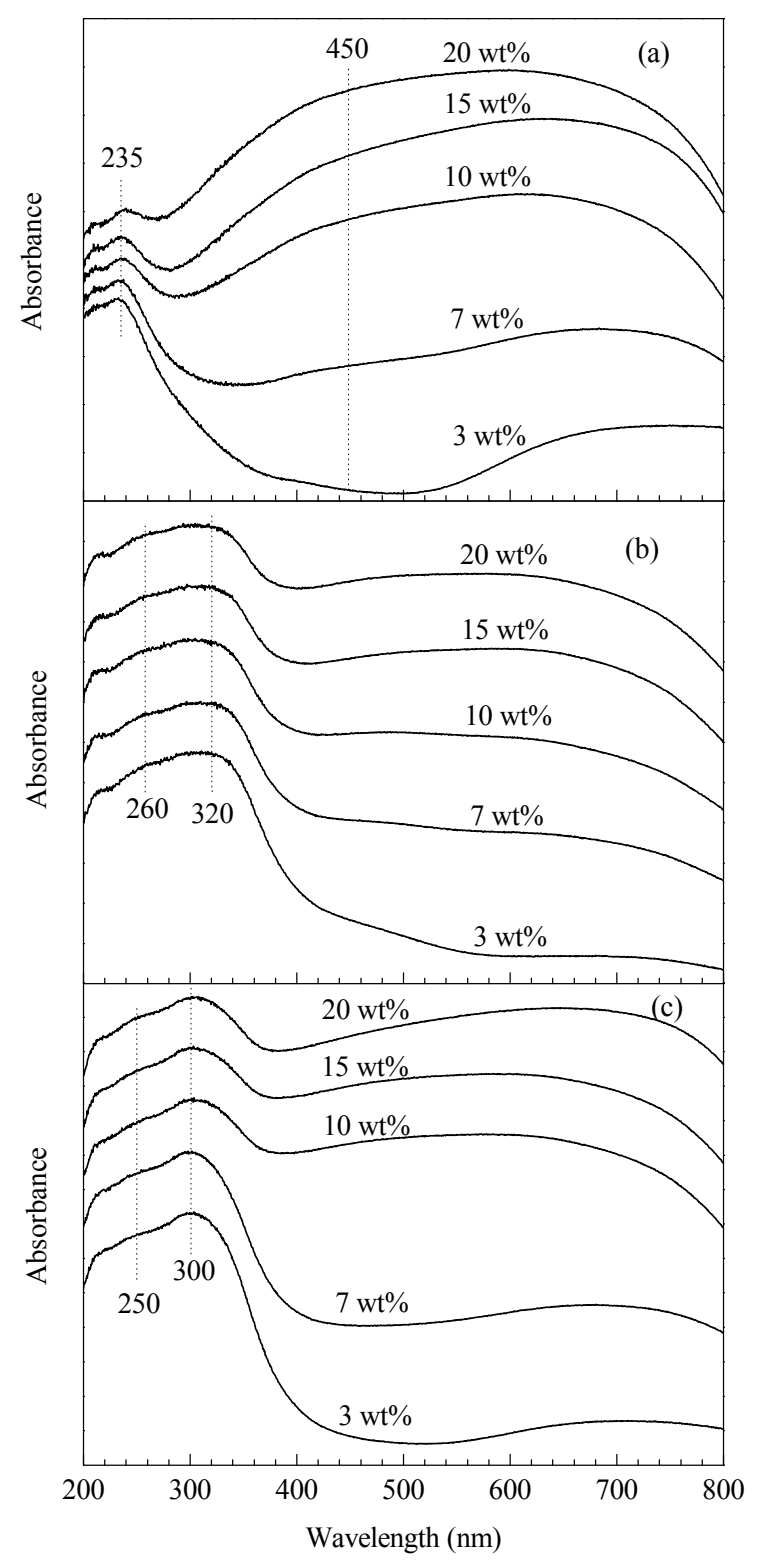

Fig. 2. UV-Vis DR spectra of $\mathrm{CuA}(\mathrm{a}), \mathrm{CuC}(\mathrm{b})$, and $\mathrm{CuCA}$ (c) catalysts with different $\mathrm{CuO}$ loadings.

consumption peaks were attributed to the reduction of the $\mathrm{Cu}$ species. Moreover, the $\mathrm{H}_{2} / \mathrm{Cu}$ ratio calculated based on the $\mathrm{H}_{2}$-TPR profiles were close to 1 for the $\mathrm{CuA}$ samples. Therefore, considering that the UV-Vis DR result suggested the existence of isolated $\mathrm{Cu}^{2+}$ ions on $\gamma-\mathrm{Al}_{2} \mathrm{O}_{3}$ at $3 \mathrm{wt} \% \mathrm{CuO}$ loading (Fig. 2(a)), we attributed the peak at $222{ }^{\circ} \mathrm{C}$ to the reduction of well-dispersed $\mathrm{Cu}^{2+}$. The peaks at 199 and 192 ${ }^{\circ} \mathrm{C}$ observed over $7 \% \mathrm{CuA}$ and $10 \% \mathrm{CuA}$, respectively, suggested the presence of $\mathrm{CuO}$ species that were reduced more readily than the isolated $\mathrm{Cu}^{2+}$ entities (reduced at $222{ }^{\circ} \mathrm{C}$ ). Larsson et al. [17] suggested that these reduction peaks can be attributed to well dispersed copper aluminate species that were different from bulk $\mathrm{CuAl}_{2} \mathrm{O}_{4}$. Wan et al. [6] considered that they were due to the occupancy of $\mathrm{Cu}^{2+}$ species at sites

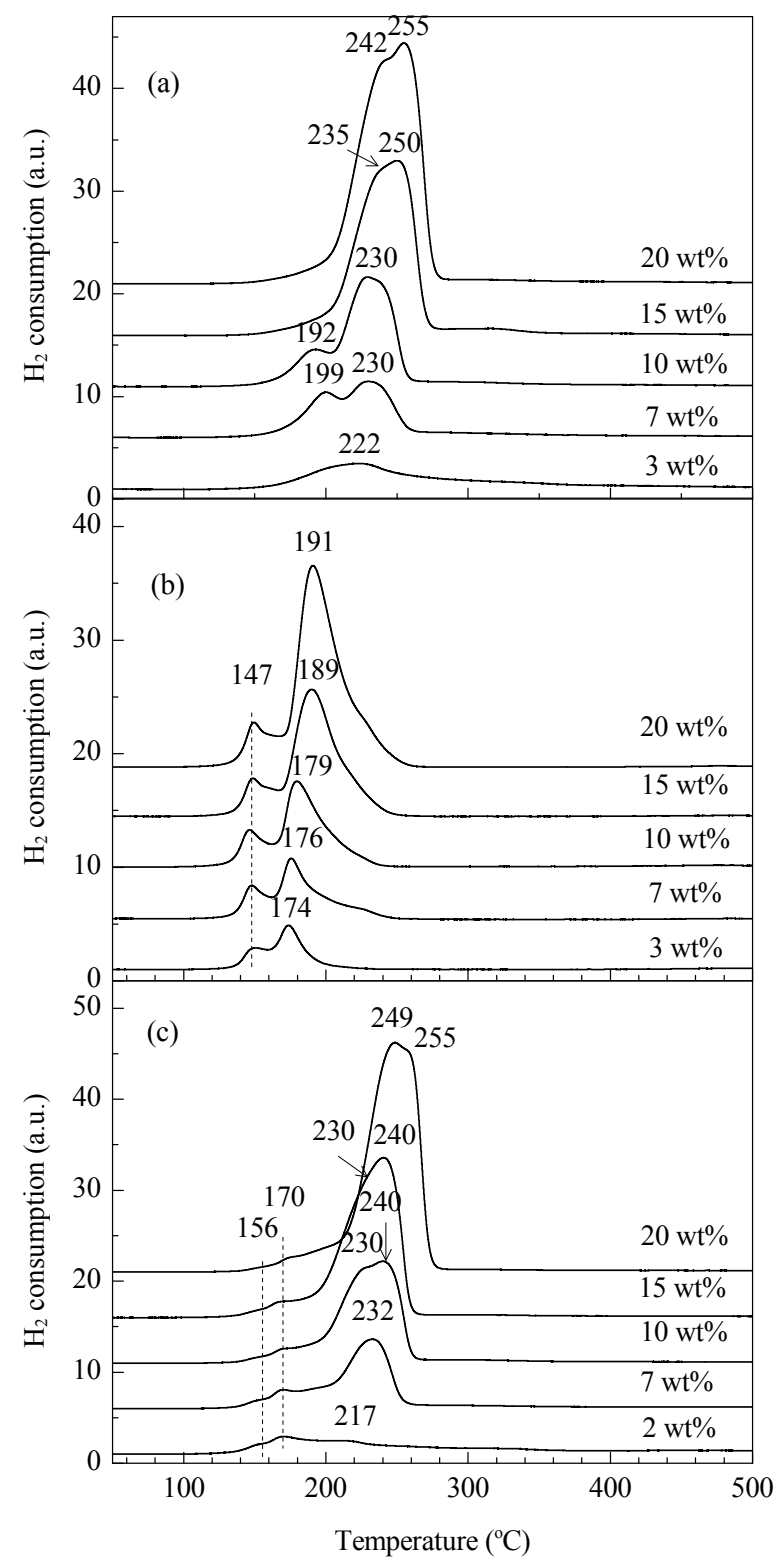

Fig. 3. TPR profiles of $\mathrm{CuA} \mathrm{(a),} \mathrm{CuC}$ (b), and $\mathrm{CuCA}$ (c) catalysts with different $\mathrm{CuO}$ loadings.

of different coordinate environments on the surface of $\gamma-\mathrm{Al}_{2} \mathrm{O}_{3}$ such as symmetric hexacoordinate and asymmetric pentacoordinate. They believed that the copper species located at the former were more facilely reduced than those located at the latter. In addition, Martinez-Arias et al. [9] suggested, based on electron paramagnetic resonance (EPR) and CO-TPR results, that $\mathrm{CuO}$ clusters could be more easily reduced than isolated $\mathrm{Cu}^{2+}$. Since the broad band at around $450 \mathrm{~nm}$ observed over $7 \% \mathrm{CuA}$ and $10 \% \mathrm{CuA}$ in the UV-Vis DR investigation (Fig. 2(a)) can be related to the formation of highly dispersed $(\mathrm{Cu}-\mathrm{O}-\mathrm{Cu})^{2+}$ clusters on $\gamma-\mathrm{Al}_{2} \mathrm{O}_{3}$, we tentatively assigned the 199 and $192{ }^{\circ} \mathrm{C}$ peaks to the reduction of $\mathrm{CuO}$ clusters. With the further increase of $\mathrm{CuO}$ loading to $15 \mathrm{wt} \%$ and $20 \mathrm{wt} \%$, the 199 and $192{ }^{\circ} \mathrm{C}$ peaks 
vanished, suggesting that highly dispersed $\mathrm{CuO}$ clusters cannot exist at such high $\mathrm{CuO}$ loadings. Based on the XRD (Fig. 1(a)) and UV-Vis (Fig. 2(a)) characterizations, we attributed the reduction peaks at or above $230{ }^{\circ} \mathrm{C}$ to the reduction of large $\mathrm{CuO}$ particles and/or bulk $\mathrm{CuO}$.

In the case of the ceria supported catalysts, the XRD patterns obtained for different $\mathrm{CuO}$ concentrations are shown in Fig. 1(b). The appearance of bulk $\mathrm{CuO}$ was seen except for the catalyst with $3 \mathrm{wt} \% \mathrm{CuO}$. The crystallite size also increased with the loading (Table 1). The UV-Vis DR spectra of these catalysts are shown in Fig. 2(b). Besides the bands at $210-270 \mathrm{~nm}$ and $600-800 \mathrm{~nm}$, there was another absorption band at $310 \mathrm{~nm}$. According to Velu et al. [18] and Turco et al. [19], bands at 300-350 nm can be assigned to charge transfer involving $\mathrm{Cu}^{2+}-\mathrm{O}-\mathrm{Cu}^{2+}$ cluster-like species that were not detectable by XRD. It was noted that unlike the $\mathrm{CuA}$ catalysts, all the $\mathrm{CuC}$ catalysts showed the $310 \mathrm{~nm}$ band, indicating that $\mathrm{CeO}_{2}$ promoted the formation of $\mathrm{CuO}$ clusters regardless of $\mathrm{CuO}$ loading (from 3 to 20 $\mathrm{wt} \%$ ). Similarly to the case of the $\mathrm{CuA}$ catalysts, an absorption edge at 740-800 $\mathrm{nm}$ was also observed over the $\mathrm{CuC}$ catalysts when the $\mathrm{CuO}$ loading was at or above $7 \mathrm{wt} \%$. The results indicated the formation of bulk $\mathrm{CuO}$, in agreement with the XRD results (Fig. 1(b)). Over the $\mathrm{CuC}$ catalysts with $\mathrm{CuO}$ loading ranging from $3 \mathrm{wt} \%$ to $20 \mathrm{wt} \%$, two $\mathrm{H}_{2}$ reduction peaks were detected (Fig. 3(b)). With increased loading, the peak at $147^{\circ} \mathrm{C}$ did not change in position while the larger peak shifted from 174 to $191{ }^{\circ} \mathrm{C}$. The increase in intensity of the small peak was less pronounced than that of the large peak. Similar TPR profiles had been reported elsewhere over $\mathrm{CeO}_{2}$-supported $\mathrm{CuO}$. $\mathrm{Hu}$ et al. [20] assigned the peaks to the two-step reduction of highly dispersed $\mathrm{Cu}^{2+}$ : first to $\mathrm{Cu}^{+}$and then to $\mathrm{Cu}^{0}$. Because the UV-Vis DR result of the $3 \% \mathrm{CuC}$ catalyst (Fig. 2(b)) demonstrated the existence of $\mathrm{Cu}^{2+}-\mathrm{O}-\mathrm{Cu}^{2+}$ clusters, we assigned the $147{ }^{\circ} \mathrm{C}$ peak to the reduction of $\mathrm{CuO}$ clusters. Accordingly, the 174 ${ }^{\circ} \mathrm{C}$ peak can be attributed to the reduction of $\mathrm{CuO}$ particles with a larger size, in agreement with the suggestions by Zheng et al. [21] and Rao et al. [22]. Actually, the calculated $\mathrm{H}_{2} / \mathrm{Cu}$ ratio was slightly higher than 1 for all the $\mathrm{CuC}$ samples, indicating that the reduction process involved surface oxygen species of the $\mathrm{CeO}_{2}$ support. Moreover, an increase in $\mathrm{CuO}$ loading resulted in an intensity increase and position shift of this peak. The results suggested the aggregation of $\mathrm{CuO}$ particles and the formation of bulk $\mathrm{CuO}$. Nonetheless, it was apparent that the $\mathrm{CuO}$ clusters observed at $3 \mathrm{wt} \%$ loading still existed. The results are in agreement with the UV-Vis DR (Fig. 2(b)) and XRD (Fig. 1(b)) results.

The XRD results for the CuCA catalysts with different $\mathrm{CuO}$ loadings (Fig. 1(c)) were similar to the $\mathrm{CuA}$ and $\mathrm{CuC}$ catalysts. At or above $7 \mathrm{wt} \% \mathrm{CuO}$ loading, bulk $\mathrm{CuO}$ peaks were pronounced, and the crystallite size was increased as shown in Table 1. Moreover, based on the strong diffraction peaks of $\mathrm{CeO}_{2}$ detected over $\mathrm{CuCA}$, it was ascertained that there were $\mathrm{CeO}_{2}$ crystallites on the $10 \% \mathrm{CeO}_{2} / \gamma-\mathrm{Al}_{2} \mathrm{O}_{3}$ binary support. It was more interesting that the UV-Vis results (Fig. 2(c)) gave similar spectra to the $\mathrm{CuC}$ catalysts. All the CuCA catalysts showed band at $300 \mathrm{~nm}$, which was attributed to $\mathrm{CuO}$ clusters, regardless of the loading. On the other hand, the TPR profiles of the CuCA catalysts had features that resembled those of $\mathrm{CuA}$ and $\mathrm{CuC}$ (Fig. 3(c)). In the 130 to $200{ }^{\circ} \mathrm{C}$ region, the features resembled those of $\mathrm{CuC}$ while in the 200 to $280{ }^{\circ} \mathrm{C}$ region, the features resembled those of $\mathrm{CuA}$. According to Fernández-García et al. [23], the TEM results of the $\mathrm{Cu} / \mathrm{CeO}_{2} / \mathrm{Al}_{2} \mathrm{O}_{3}$ catalyst suggested the preferential nucleation of $\mathrm{CuO}$ on regions that were rich with $\mathrm{CeO}_{2}$. As illustrated above, the CuCA catalysts showed strong XRD signals of $\mathrm{CeO}_{2}$ (Fig. 1(c)) as well as the strong absorption band of $\mathrm{CuO}$ clusters at $300 \mathrm{~nm}$ (Fig. 2(c)). We thus associate the peaks at 156 and $170{ }^{\circ} \mathrm{C}$, respectively, to the reduction of $\mathrm{CuO}$ clusters and large $\mathrm{CuO}$ particles on $\mathrm{CeO}_{2}$, and the peaks located in the 200 to $280{ }^{\circ} \mathrm{C}$ region to $\mathrm{CuO}$ species on $\gamma-\mathrm{Al}_{2} \mathrm{O}_{3}$. With an increase in $\mathrm{CuO}$ loading, the peaks at 156 and $170{ }^{\circ} \mathrm{C}$ remained unchanged in position, similar to that observed over $\mathrm{CuC}$ (Fig. 3(b)).

\subsection{Investigation on thermal aging resistance}

After thermal aging $\left(950{ }^{\circ} \mathrm{C}\right.$ for $\left.4 \mathrm{~h}\right)$, the XRD patterns of $\mathrm{CuO}$ observed over $7 \% \mathrm{CuA}$ were not detected (Fig. 4). It is plausible to consider that during the aging process, there was the formation of $\mathrm{CuAl}_{2} \mathrm{O}_{4}$ due to $\mathrm{Cu}^{2+}$ incorporation into tetrahedral vacancies. Its generation was supported by the pronounced adsorption in the UV-Vis DR spectra (Fig. 5). According to Chen et al. [15], bulk-like $\mathrm{CuAl}_{2} \mathrm{O}_{4}$ shows absorption at 400-500 nm, and that was the case with the $7 \% \mathrm{CuA}-\mathrm{a}$ sample. By considering that the temperature

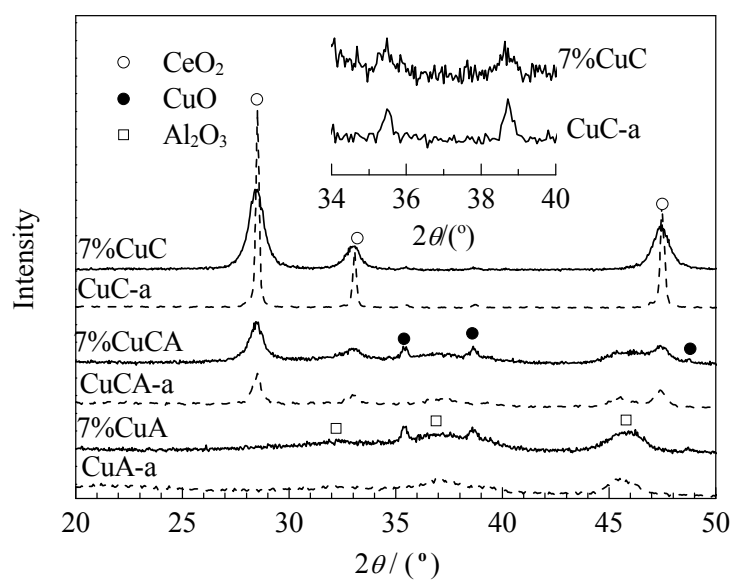

Fig. 4. XRD patterns of fresh and aged (broken line) $\mathrm{CuA}, \mathrm{CuC}$, and CuCA catalysts. 


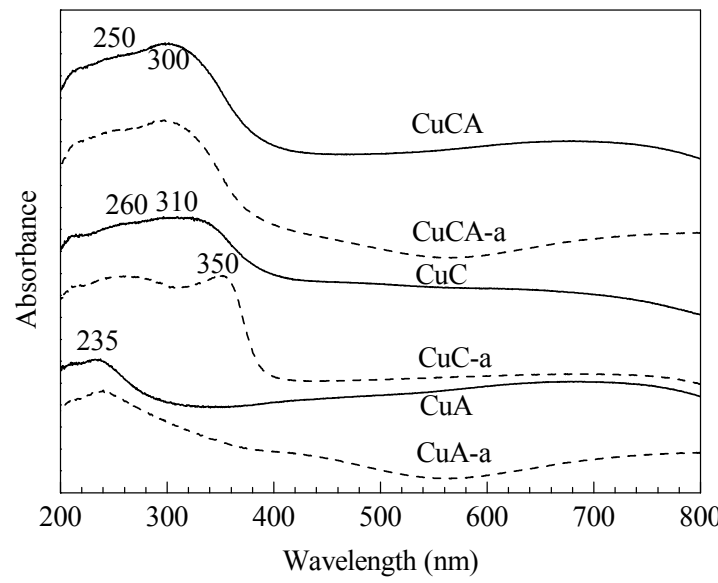

Fig. 5. UV-Vis DR spectra of fresh and aged (broken line) $\mathrm{CuA}, \mathrm{CuC}$ and CuCA catalysts.

adopted for aging was much higher than that for fresh catalyst calcining, this suggestion is reasonable. However, we detected no XRD peaks over CuA-a that could be related to $\mathrm{CuAl}_{2} \mathrm{O}_{4}$ crystallites, which was plausibly because the $\mathrm{CuAl}_{2} \mathrm{O}_{4}$ were dispersed copper aluminate species. In addition, the absorption band at $235 \mathrm{~nm}$ observed with $7 \% \mathrm{CuA}$ was shifted to $240 \mathrm{~nm}$ after thermal aging. This was probably due to some slight aggregation of $\mathrm{CuO}$ entities. In the TPR investigation (Fig. 6), the $199^{\circ} \mathrm{C}$ peak detected over $7 \% \mathrm{CuA}$ was significantly decreased in intensity after aging. This indicated the sintering of $\mathrm{CuO}$ species, which was consistent with the UV-Vis DR results. Moreover, a new reduction peak at $282{ }^{\circ} \mathrm{C}$ was detected over $\mathrm{CuA}-\mathrm{a}$, which could be attributed to the reduction of $\mathrm{CuO}$ from $\mathrm{CuAl}_{2} \mathrm{O}_{4}$.

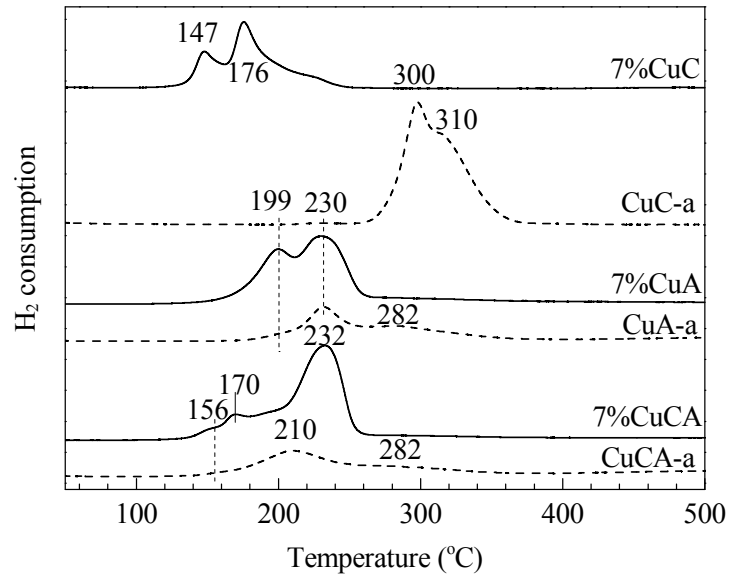

Fig. 6. TPR profiles of fresh and aged (broken line) $\mathrm{CuA}, \mathrm{CuC}$, and CuCA catalysts.

After aging, all the XRD peaks of $\mathrm{CuC}$-a were sharpened as shown in Fig. 4. This showed the occurrence of $\mathrm{CeO}_{2}$ sintering and $\mathrm{CuO}$ aggregation during the thermal process. From the inset in the pattern, the increase in intensity of $\mathrm{CuO}$ was more pronounced. The changes of crystallite sizes of ceria (cubic) and copper oxide during the aging process are also shown in Table 1. Upon thermal aging of $7 \% \mathrm{CuC}$ at $950{ }^{\circ} \mathrm{C}$, the crystallite size of $\mathrm{CeO}_{2}$ and $\mathrm{CuO}$ changed from 12 to $63 \mathrm{~nm}$ and from 18 to $32 \mathrm{~nm}$, respectively. There was also a significant change in absorbance: the band at $310 \mathrm{~nm}$ observed over $7 \% \mathrm{CuC}$ was shifted to $350 \mathrm{~nm}$ after aging (Fig. 5). This showed that there was a dramatically increase of $\mathrm{CuO}$ particle size. The change in the TPR profile was even more drastic: over $7 \% \mathrm{CuC}$, reduction occurred at 147 and $176{ }^{\circ} \mathrm{C}$; over $\mathrm{CuC}$-a, it occurred at 300 and $310{ }^{\circ} \mathrm{C}$, which was a shift of nearly $150{ }^{\circ} \mathrm{C}$ (Fig. 6). It is clear that after aging, the catalyst became more difficult to reduce, and that was accompanied by the aggregation of $\mathrm{CuO}$ particles and the disappearance of copper oxide clusters.

As for the $7 \% \mathrm{CuCA}$ catalyst, the XRD peaks of $\mathrm{Al}_{2} \mathrm{O}_{3}$ and $\mathrm{CeO}_{2}$ sharpened while those of $\mathrm{CuO}$ disappeared after thermal aging (Fig. 4). From Table 1, one can see that the change in particle size of $\mathrm{CeO}_{2}$ from 13 to $17 \mathrm{~nm}$ by aging is insignificant. The UV-Vis DR spectrum of CuCA-a showed absorption bands at 250 and $300 \mathrm{~nm}$, and compared with those of 7\% CuCA (Fig. 5) there was no significant shift in this position. In addition, there was a new adsorption band at $400-500 \mathrm{~nm}$, which was similar to that observed over $\mathrm{CuA}-\mathrm{a}$, which demonstrated the existence of $\mathrm{CuAl}_{2} \mathrm{O}_{4}$. The TPR profiles of Fig. 6 suggested the formation of $\mathrm{CuAl}_{2} \mathrm{O}_{4}$ (reduction peak of $\mathrm{CuO}$ at $282{ }^{\circ} \mathrm{C}$ ) and the disappearance of larger $\mathrm{CuO}$ particles that had existed on $\mathrm{CeO}_{2}$ (reduction peak at $170{ }^{\circ} \mathrm{C}$ ). It should be noted that $\mathrm{CuO}$ clusters (reduction peak at $156{ }^{\circ} \mathrm{C}$ ) still existed despite the high aging temperature. Furthermore, the disappearance of the $232{ }^{\circ} \mathrm{C}$ peak detected over $7 \% \mathrm{CuCA}$ and the generation of the $210{ }^{\circ} \mathrm{C}$ peak over CuCA-a were defected. The results suggested that due to high temperature aging, there was strengthened $\mathrm{CuO} / \mathrm{Al}_{2} \mathrm{O}_{3}$ interaction and occupancy of the surface tetrahedral vacancy sites on $\gamma-\mathrm{Al}_{2} \mathrm{O}_{3}$ [7]. With $\mathrm{CuAl}_{2} \mathrm{O}_{4}$ formation, the remaining copper oxide species (reduced at $210{ }^{\circ} \mathrm{C}$ ) had less interaction with the support.

\subsection{Catalytic activity}

The catalytic performance of freshly calcined $7 \% \mathrm{CuA}$, $7 \% \mathrm{CuC}$, and $7 \% \mathrm{CuCA}$ catalysts are shown in Fig. 7. $7 \% \mathrm{CuCA}$ was superior to $7 \% \mathrm{CuA}$ in $\mathrm{CO}, \mathrm{NO}$, and $\mathrm{C}_{3} \mathrm{H}_{6}$ conversion. The result indicated that the presence of $\mathrm{CeO}_{2}$ on $\gamma-\mathrm{Al}_{2} \mathrm{O}_{3}$ enhanced the oxidation activity of $\mathrm{CuO}$. On the other hand, $7 \% \mathrm{CuCA}$ was superior to $7 \% \mathrm{CuC}$ for $\mathrm{NO}$ conversion (in the $200-350{ }^{\circ} \mathrm{C}$ range only), but was inferior to $\mathrm{CuC}$ for $\mathrm{CO}$ and $\mathrm{C}_{3} \mathrm{H}_{6}$ conversion. Nonetheless, the fresh and aged $\mathrm{CuO}$ catalysts showed a similar decline in the conversion of the three pollutants. However, the CuCA-a catalyst retained a superior performance, which was similar to that of $7 \% \mathrm{CuCA}$. The aging effect was most detrimental 


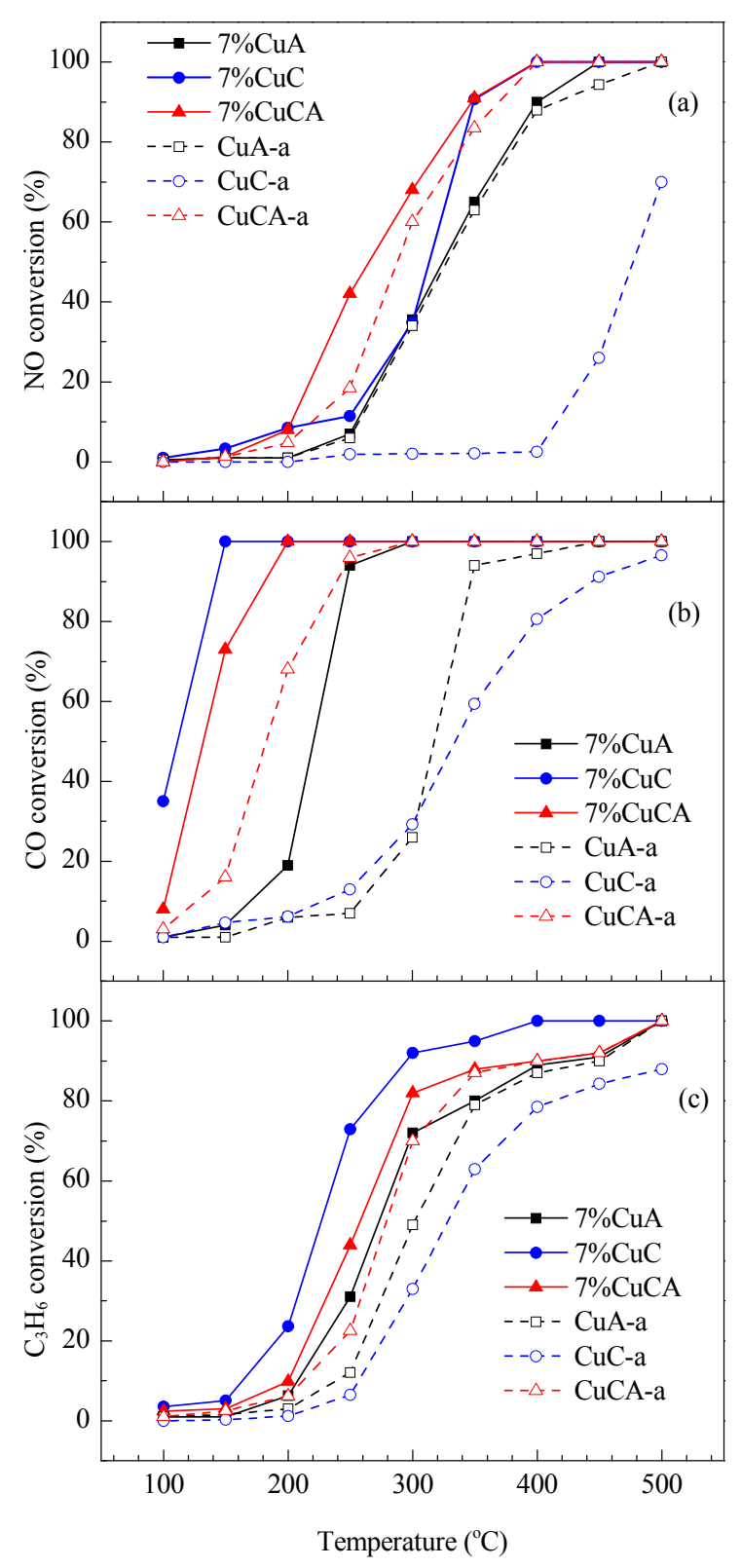

Fig. 7. Catalytic performance of fresh and aged (broken line) $\mathrm{CuA}$, $\mathrm{CuC}$, and CuCA catalysts. Gas composition: $0.1 \% \mathrm{NO}, 1 \% \mathrm{CO}, 0.1 \%$ $\mathrm{C}_{3} \mathrm{H}_{6}, 0.9 \% \mathrm{O}_{2}, \mathrm{~N}_{2}$ balance, GHSV $=50000 \mathrm{~h}^{-1}$.

on the $\mathrm{CuC}$-a catalyst, and the $\mathrm{CuC}$-a catalyst was the least effective in eliminating $\mathrm{NO}$ in the low temperature region $\left(100-400{ }^{\circ} \mathrm{C}\right)$. Overall, in terms of the simultaneous removal of $\mathrm{NO}, \mathrm{CO}$, and $\mathrm{C}_{3} \mathrm{H}_{6}$ as well as stability of activity against thermal aging, the $7 \% \mathrm{CuCA}$ catalyst was the best among the catalysts.

\subsection{Relation between copper oxide clusters and catalytic performance}

In the cases of the freshly calcined $\mathrm{CuA}$ catalysts, the TPR and UV-vis DR investigations revealed that $\mathrm{CuO}$ ex- isted as isolated $\mathrm{Cu}^{2+}$ and in the form of clusters at or below $10 \mathrm{wt} \% \mathrm{CuO}$ loading. At higher $\mathrm{CuO}$ loadings, both the XRD signals and UV-Vis DR peaks of bulk $\mathrm{CuO}$ appeared and there was the disappearance of the $\mathrm{CuO}$ clusters as confirmed in the TPR studies. The results clearly demonstrated that with increased $\mathrm{CuO}$ loading, $\mathrm{CuO}$ on $\gamma-\mathrm{Al}_{2} \mathrm{O}_{3}$ changed from isolated $\mathrm{Cu}^{2+}$ to $\mathrm{CuO}$ clusters and then aggregated into bulk $\mathrm{CuO}$. For the $\mathrm{CuC}$ catalysts with $3 \mathrm{wt} \% \mathrm{CuO}$ loading, the XRD results showed no signal of $\mathrm{CuO}$ crystallites, and the UV-Vis DR and TPR results indicated that the copper species was in the form of $\mathrm{Cu}^{2+}$ clusters. At higher $\mathrm{CuO}$ loading, there was formation of bulk $\mathrm{CuO}$ as shown by the XRD, UV-Vis DR, and TPR results. However, considering that the low temperature reduction peak at $147{ }^{\circ} \mathrm{C}$ in the TPR profiles did not change in position regardless of the increase in $\mathrm{CuO}$ loading, we deduced that there were always some $\mathrm{CuO}$ clusters on the surface of $\mathrm{CeO}_{2}$. Over the $\mathrm{CuCA}$ catalysts, we observed results similar to those of $\mathrm{CuC}$. We found the existence of $\mathrm{CuO}$ clusters regardless of the increase in $\mathrm{CuO}$ loading. In other words, there was the coexistence of $\mathrm{CuO}$ clusters and larger $\mathrm{CuO}$ particles, which were dispersed on the surface of $\mathrm{CeO}_{2}$, and the aggregation of copper species seemed to occur on $\gamma-\mathrm{Al}_{2} \mathrm{O}_{3}$.

By comparing the states of the copper species on $\mathrm{CuA}$, $\mathrm{CuC}$, and $\mathrm{CuCA}$, one can deduce: (i) $\gamma-\mathrm{Al}_{2} \mathrm{O}_{3}$ can disperse active copper components but cannot stabilize them due to the relatively weak interaction between $\mathrm{CuO}$ and $\gamma-\mathrm{Al}_{2} \mathrm{O}_{3}$, and with increasing $\mathrm{CuO}$ loading, there was aggregation of small particles and formation of bulk $\mathrm{CuO}$, and (ii) dispersed copper oxide species can be stabilized on $\mathrm{CeO}_{2}$ due to strong interaction of $\mathrm{CuO}$ with $\mathrm{CeO}_{2}$, and $\mathrm{CuO}$ clusters can stably exist on the $\mathrm{CuC}$ and $\mathrm{CuCA}$ catalysts even when there was aggregation of copper oxide species on the surface of the catalysts.

As to the thermal stability of the $\mathrm{CuO}$ clusters, the $\mathrm{CuA}-\mathrm{a}$ characterization results suggested the conversion of $\mathrm{CuO}$ crystallites to bulk-like $\mathrm{CuAl}_{2} \mathrm{O}_{4}$ species during thermal aging at $950{ }^{\circ} \mathrm{C}$. Moreover, the UV-Vis DR and TPR results demonstrated the aggregation of copper species on $\gamma-\mathrm{Al}_{2} \mathrm{O}_{3}$ after aging. It is apparent that $\mathrm{CuC}$-a was significantly different from $\mathrm{CuC}$ as indicated by the $\mathrm{XRD}, \mathrm{UV}-\mathrm{V}$ is $\mathrm{DR}$, and TPR results due to the severe sintering of $\mathrm{CeO}_{2}$. In particular, the TPR results indicated severe aggregation of copper species and the complete disappearance of $\mathrm{CuO}$ clusters. There was, however, UV-Vis DR and TPR evidence for the presence of $\mathrm{CuO}$ clusters on CuCA-a. Despite the high temperature and the formation of $\mathrm{CuAl}_{2} \mathrm{O}_{4}$, some $\mathrm{CuO}$ clusters survived the aging treatment.

With the correlation of the existence of $\mathrm{CuO}$ clusters and catalytic behavior, the significance of $\mathrm{CuO}$ species stability on catalytic performance is more significant. Based on the TPR results, one knows that the $\mathrm{CuC}$ and $\mathrm{CuCA}$ catalysts 
were easily reduced because of the stable $\mathrm{CuO}$ clusters generated by the strong $\mathrm{CuO} / \mathrm{CeO}_{2}$ interaction. Due to this, they showed catalytic activity better than that of $\mathrm{CuA}$, especially for $\mathrm{CO}$ and $\mathrm{C}_{3} \mathrm{H}_{6}$ oxidation. Nonetheless, compared with $\mathrm{CuCA}, \mathrm{CuC}$ was less able to retain $\mathrm{CuO}$ clusters during a thermal treatment. As a result of $\mathrm{CeO}_{2}$ sintering and the disappearance of $\mathrm{CuO}$ clusters, $\mathrm{CuC}$-a had poor activity. $\mathrm{On}$ the other hand, $\gamma-\mathrm{Al}_{2} \mathrm{O}_{3}$ in $\mathrm{CuCA}$ stabilized the $\mathrm{CeO}_{2}$ particles during the thermal process. The detection of $\mathrm{CuO}$ clusters on $\mathrm{CuCA}-\mathrm{a}$ was strong evidence that $\gamma-\mathrm{Al}_{2} \mathrm{O}_{3}$ stabilized $\mathrm{CeO}_{2}$ against sintering. It is because of the presence of $\mathrm{CuO}$ clusters on CuCA-a that had a satisfactory activity.

In summary, $\gamma-\mathrm{Al}_{2} \mathrm{O}_{3}$ can disperse but cannot stabilize $\mathrm{CuO}$ species while the promotion of $\gamma-\mathrm{Al}_{2} \mathrm{O}_{3}$ with $\mathrm{CeO}_{2}$ can result in $\mathrm{CuO}$ being stabilized, which remained in the form of clusters. Under severe thermal condition such as aging at $950{ }^{\circ} \mathrm{C}, \mathrm{CeO}_{2}$ alone cannot stabilize $\mathrm{CuO}$ clusters but the co-existence of both $\mathrm{CeO}_{2}$ and $\gamma-\mathrm{Al}_{2} \mathrm{O}_{3}$ resulted in some $\mathrm{CuO}$ clusters remaining. We attribute the good and stable performance of $7 \% \mathrm{CuCA}$ to the high dispersion and thermal stability of the $\mathrm{CuO}$ clusters. Among the catalysts investigated in this study, $7 \% \mathrm{CuCA}$ performed the best, and the highly dispersed $\mathrm{CuO}$ species are believed to be active in the removal of $\mathrm{CO}, \mathrm{NO}$, and $\mathrm{C}_{3} \mathrm{H}_{6}$.

\section{Conclusions}

Due to the relatively weak interaction between $\mathrm{CuO}$ and $\gamma-\mathrm{Al}_{2} \mathrm{O}_{3}, \mathrm{CuO}$ is well dispersed on $\gamma-\mathrm{Al}_{2} \mathrm{O}_{3}$ below $3 \mathrm{wt} \%$ loading. With increased $\mathrm{CuO}$ loading above $3 \mathrm{wt} \%, \gamma-\mathrm{Al}_{2} \mathrm{O}_{3}$ fails to maintain $\mathrm{CuO}$ as a well dispersed species and $\mathrm{CuO}$ existed as clusters and then gradually as bulk particles. On the other hand, due to the strong interaction between $\mathrm{CuO}$ and $\mathrm{CeO}_{2}$, there were always some $\mathrm{CuO}$ clusters on the $\mathrm{CuO} / \mathrm{CeO}_{2}$ catalysts regardless of how high the $\mathrm{CuO}$ loading was. However, after thermal aging treatment at $950{ }^{\circ} \mathrm{C}$ for $4 \mathrm{~h}, \mathrm{CuO}$ clusters dispersed on $\mathrm{CeO}_{2}$ were severely sintered due to the poor thermal stability of the support. Accordingly, by pre-dispersing $\mathrm{CeO}_{2}$ on $\gamma-\mathrm{Al}_{2} \mathrm{O}_{3}$ followed by dispersing $\mathrm{CuO}$ on $\mathrm{CeO}_{2}, \mathrm{CuO}$ clusters were stabilized due to the better aging resistance of $\gamma-\mathrm{Al}_{2} \mathrm{O}_{3}$. Consequently, as compared with $\mathrm{CuO} / \gamma-\mathrm{Al}_{2} \mathrm{O}_{3}$ and $\mathrm{CuO} / \mathrm{CeO}_{2}$, a $\mathrm{CuO} / \mathrm{CeO}_{2} / \gamma-\mathrm{Al}_{2} \mathrm{O}_{3}$ catalyst gave better catalytic performances and thermal aging properties. Therefore, stabilized $\mathrm{CuO}$ clusters are important as the active species for the re- moval of $\mathrm{CO}$, $\mathrm{NO}$, and $\mathrm{C}_{3} \mathrm{H}_{6}$.

\section{References}

1 Douidah A, Marecot P, Szabo S, Barbier J. Appl Catal A, 2002, 225: 21

2 Soled S L, Iglesia E, Fiato R A, Baumgartner J E, Vroman H, Miseo S. Top Catal, 2003, 26: 101

3 Backman L B, Rautiainen A, Lindblad M, Krause A O I. Appl Catal A, 2009, 360: 183

4 An W Z, Chuang K T, Sanger A R. J Catal, 2002, 211: 308

$5 \mathrm{Hu}$ Y H, Dong L, Wang J, Ding W P, Chen Y. J Mol Catal A, 2000, 162: 307

6 Wan H Q, Wang Z, Zhu J, Li X W, Liu B, Gao F, Dong L, Chen Y. Appl Catal B, 2008, 79: 254

7 Park P W, Ledford J S. Catal Lett, 1998, 50: 41

8 Jacobs G, Das T K, Zhang Y Q, Li J L, Racoillet G, Davis B H. Appl Catal A, 2002, 233: 263

9 Martinez-Arias A, Cataluna R, Conesa J C, Soria J. J Phys Chem B, 1998, 102: 809

10 郭锡坤, 贾海建, 范倩玉, 李文衍, 刘伟明. 催化学报 (Guo X K, Jia H J, Fan Q Y, Li W Y, Liu W Y. Chin J Catal), 2009, 30: 124

11 郭锡坤, 林树东. 催化学报 (Guo X K, Lin Sh D. Chin J Catal), 2008, 29: 221

12 董林. 催化学报 (Dong L. Chin J Catal), 2009, 30: 1150

13 Praliaud H, Mikhailenko S, Chajar Z, Primet M. Appl Catal B, 1998, 16: 359

14 Chary K V R, Sagar G V, Naresh D, Seela K K, Sridhar B. J Phys Chem B, 2005, 109: 9437

15 Chen L Y, Horiuchi T, Osaki T, Mori T. Appl Catal B, 1999, 23: 259

16 de Carvalho M C N A, Passos F B, Schmal M. Appl Catal A, 2000, 193: 265

17 Larsson P O, Andersson A. Appl Catal B, 2000, 24: 175

18 Velu S, Suzuki K, Okazaki M, Kapoor M P, Osaki T, Ohashi F. J Catal, 2000, 194: 373

19 Turco M, Bagnasco G, Costantino U, Marmottini F, Montanari T, Ramis G, Busca G. J Catal, 2004, 228: 43

$20 \mathrm{Hu}$ Y H, Dong L, Shen M M, Liu D, Wang J, Ding W P, Chen Y. Appl Catal B, 2001, 31: 61

21 Zheng X C, Zhang X L, Wang X Y, Wang S R, Wu S H. Appl Catal A, 2005, 295: 142

22 Rao G R, Sahu H R, Mishra B G. Colloid Surf A, 2003, 220: 261

23 Fernández-García M, Gómez Rebollo E, Guerrero Ruiz A, Conesa J C, Soria J. J Catal, 1997, 172: 146 